\title{
OBRAZ PSYCHOZY W AUTOBIOGRAFICZNEJ TWÓRCZOŚCI LITERACKIEJ OSÓB CHORUJĄCYCH PSYCHICZNIE
}

\begin{abstract}
Image of psychosis in autobiographical literary work of mentally ill people

Both superficial and professional contact with a person suffering from paranoid schizophrenia brings with it many threads, questions and ambiguities. This is also the case with contact with the literary and poetic work of the people affected. Their work is often incomprehensible, because in its form it often does not resemble anything known, simple or familiar. Reading the products of the sick, we have a chance to get closer to the experience and to get to know psychosis, but also to get closer to the author, as to the man with a burden on the neck, but as valuable as all other people. The aim of this work is to introduce the subject of narration and autobiographical work of mentally ill people on the example of Joanne Greenberg's novel "Life is not a fairy tale".
\end{abstract}

Keywords: schizophrenia, autonarration, literary work, psychosis, art brut, the art of excluded

\section{Wstęp}

Próba wejścia w istnienie drugiego człowieka może okazać się wspaniałą przygodą. Miejmy jednak świadomość, że bios - życie, zawsze zwycięża nad gráphô - a więc życie zwycięża nad pisaniem o nim. Indywidualna, jednostkowa egzystencja jest zawsze większa i pełniejsza od historii ją opisującej (Czaja 2004: 7). Nie jest to jednak przeszkodą uniemożliwiającą zainteresowanie się taką tematyką. Niniejsze opracowanie stawia sobie za cel bliższe poznanie narracji osób chorujących na schizofrenię paranoidalną, a więc historii ich życia. Wielu badaczy sądzi przy tym, że sposób myślenia strukturalizuje się od momentu narodzin (Golańska 2007). Należy jednak zastanowić się, czy początki życia umysłowego nie dotyczą już okresu płodowego (Paul-Cavallier 2001: 45). To w nim w wielu przypadkach powinniśmy szukać źródeł choroby.

Mottem opracowania uczyńmy słowa Joanne Greenberg: „Musimy kiedyś wymyślić test, który pokaże, gdzie jest zdrowie, a nie tylko, gdzie jest choroba” (Greenberg

\footnotetext{
${ }^{1}$ Absolwentka pracy socjalnej w Instytucie Socjologii Uniwersytetu Jagiellońskiego w Krakowie.
} 
1994: 17). Dzięki lekturze autobiograficznej twórczości osób chorujących psychicznie można bez wątpienia dojść do wniosku, że choroba jest tylko częścią doświadczenia tych osób i potrafią one znaleźć w sobie tę moc, aby przełożyć na język sztuki to, co stanowi ich intymny świat, który tkwi głęboko w ich wnętrzu, czasem wybuchając pod postacią psychozy.

\section{Poszukiwanie sensu}

Antoni Kępiński napisał kiedyś, że każdy człowiek jest niewątpliwie sam dla siebie zagadką, i takąż stanowi dla otoczenia (Kępiński 1997: 28). Stawia pytania o to, kim jest i jakie znaczenie ma dla świata. Zwykle do tego zagadnienia próbuje odnieść się medycyna i psychologia oraz inne nauki społeczne. Tak jak pisał Kępiński - psychiatra szuka odpowiedzi na pytanie, jaki jest człowiek naprawdę? Co kryje się pod maską jego mimiki, gestów i słów? Poszukiwania sensu życia, pomyślności, harmonii w umyśle i ciele są jak najbardziej naturalne i na wskroś ludzkie, a co za tym idzie, obecne były od zarania dziejów, w każdej kulturze i środowisku.

Poszukiwanie sensu to zawsze próba odnalezienia znaczenia, a także sensu utraconego, na przykład z powodu choroby. Ludzką egzystencję, jak ujął to Victor Frankl, charakteryzuje wolność, zdolność podejmowania decyzji i odpowiedzialność (Frankl 2013). Choroba psychiczna przerywa ten ciąg - wolność przemienia się w zależność od objawów, decyzje podejmowane są z trudem lub ich podejmowanie staje się zupełnie niemożliwe, zanika zdolność do odpowiedzialności za innych i za siebie. Dramat ten może mieć jednak rozwiązanie: jest nim farmakoterapia wraz z psychoterapią, na przykład logoterapią, opracowaną przez wspomnianego wyżej Frankla, który za jej pomocą chciał mieć wgląd w duchowy wymiar ludzkości i widział siebie jako jego obrońcę. Zdaniem badacza poszukiwanie sensu było najważniejszą, niepowtarzalną i podstawową motywacją w życiu każdego $\mathrm{z}$ nas.

Podczas sesji terapeutycznych, właściwie niezależnie od ich nurtu, pacjent z pomocą terapeuty próbuje odnaleźć nie tylko sens życia, ale także sens objawów choroby, to co one znaczą, z jakim obszarem życia są związane, do czego się odnoszą. Każda godzina spędzona $\mathrm{w}$ gabinecie terapeuty przybliża do rozpoznania sensu pojawiających się trudności, do odnalezienia odpowiedzi na nurtujące pytania oraz pomaga wejść na ścieżkę rozumienia siebie i własnego miejsca w społeczeństwie.

Sens życia można odnajdywać w jego uporządkowaniu. Człowiek postępuje wedle zasad, wyznaje pewne wartości. Ma wytyczoną drogę, z której stara się nie zbaczać. Choroba psychiczna, pojawiając się często nagle i niespodziewanie, niszczy ten porządek, doprowadza do wybuchu entropii, chaosu i zagubienia. Człowiek, stając się od tej chwili pacjentem, musi na powrót odnaleźć swoją racjonalną świadomość i dążyć do przywrócenia sensu własnemu życiu.

$\mathrm{Z}$ tego powodu choroba psychiczna jest bardzo wyczerpująca. Nawet jeżeli dana osoba nie żyje na najwyższych obrotach - stosując miarę obiektywną - wewnątrz siebie 
przeżywa batalie tak gwałtowne, że można by obdzielić jej emocjami i czynami niejednego zdrowego. W nie dość odległej przeszłości wewnętrzny świat chorych był niedostępny dla lekarzy, a tym bardziej reszty społeczeństwa. Pacjent cierpiał, ale na zewnątrz ujawniały się tylko jego irracjonalne zachowania, niespójne myślenie, agresja. Dopiero wprowadzenie w latach pięćdziesiątych XX wieku leków neuroleptycznych umożliwiło skuteczniejszą walkę z psychozą i zbliżenie się do świata ludzi chorych za pomocą pewnego rodzaju wejścia w ich sposób odbioru rzeczywistości. Pacjenci nauczyli się dzielić treścią swoich psychoz z otoczeniem. Proces chorobowy jest niewątpliwie ciężkim przeżyciem, ale, jak pisał Ernest Hemingway: „człowieka można zniszczyć, ale nie pokonać" (Hemingway 1988: 46). Choroba niszczy, ale może być uleczalna, gdy tylko specjaliści i otoczenie będą prowadzić uważny i empatyczny dialog z człowiekiem oraz zauważą jego talenty i zasoby, na których można będzie budować rekonwalescencję.

Poszukiwanie sensu jest także związane z podążaniem właściwą drogą. Kępiński napisał: „Subiektywnie odczuwa się ewolucję własnych form czynnościowych jako potrzebę aktywności - aktywności twórczej, w której przekształca się zarówno siebie, jak i otaczający świat według własnego planu” (Kępiński 2001: 92). Należy bowiem dążyć do osobistego rozwoju i rzetelnego pojmowania świata. Dzięki pracy nad sobą i ciągłej walce z trudnościami jesteśmy w stanie przemienić życie mdłe i pozbawione sensu w wartościowe doświadczenie, a pierwotną słabość przykryć wzmożoną siłą. Chodzi właśnie o życie, które pokazało, jak bardzo wiele dobra może dać światu od siebie. Wzbudzać zdumienie, zachwyt oraz nadzieję dla innych chorujących, udowadniając, że cierpienie to tylko część ich doświadczenia, z której jednak można wyrzeźbić trwałe poczucie sensu.

Dla filozofa sens życia jest wprawdzie niemożliwy do odnalezienia, ale stanowi cel, który człowiek stawia przed sobą z biegiem lat. Bruno Schulz stwierdził, że „największym nieszczęściem jest nie wyżyć życia” (Schulz 2013: 163). Jest to ważna konstatacja w kontekście funkcjonowania osób chorujących psychicznie, ponieważ często nie mogą żyć pełnią życia - z powodu bólu egzystencjalnego, niedomagania, lęków czy odosobnienia. Co wobec tego znaczy „wyżyć życie”? Być uważnym, znać siebie i swoje granice, realizować marzenia, mieć bliskie osoby wokół siebie, prawidłowe relacje z innymi. Elementów tych może brakować w życiu chorujących psychicznie. Wydaje się bowiem, iż człowiek doświadczający psychozy schizofrenicznej utracił poczucie sensu swego dotychczasowego życia oraz przebywania w społeczeństwie. Jest zmęczony fałszywymi regułami gry, kłamstwem i pogonią za dobrami materialnymi. Jego uwaga zwraca się w inną stronę, eksploruje przestrzenie, które do tej pory były zakryte, drzemały w podświadomości. Może dziać się to powoli i stopniowo, może też być jednak epizodem ostrym - burzą zmiatającą to, czym do tej pory był dany człowiek. Na początku bywa to odbierane jak poznanie prawdy o świecie i sobie samym, a świadomość rozpoczynającej się choroby jest nikła. Jednostka dokonuje przemiany, jest kimś zupełnie innym niż do tej pory. Bogiem lub demonem, władcą lub uwięzionym. Jest to nowy, urojony sens egzystencji. Odejście od niego i doprowadzenie chorego do „rzeczywistości” bywa zadaniem karkołomnym. Chodzi przy tym o to, by, jak napisał Antoine de Saint-Exupéry, 
„bycie człowiekiem było czuciem, iż kładąc swoją cegłę, bierze się udział w budowaniu świata" (Saint-Exupéry 1993).

Zarówno pacjent, jak i terapeuta muszą zawrzeć przymierze uważności, bacznej obserwacji ujawnionego stanu. Jest to tak zwany wgląd w chorobę, jeden z warunków jej wyleczenia. „Współcześnie wgląd w chorobę definiuje się jako złożony fenomen obejmujący rozpoznawanie obecności zaburzeń psychicznych, ich następstw społecznych, postawę wobec leczenia, a także identyfikowanie poszczególnych objawów i umiejętność dostrzeżenia ich chorobowego pochodzenia" (Niedźwiedzka 2008: 943-957). Co więcej, uzyskanie wglądu w chorobę wykazuje implikacje kliniczne związane między innymi z poziomem współpracy w leczeniu oraz z funkcjonowaniem społecznym.

Uważa się, że zjawisko wglądu powinno być rozpatrywane wielowymiarowo, a badania nad czynnikami, które specyficznie wiążą się z gorszym wglądem mogą mieć kluczowe znaczenie dla rozumienia zaburzeń funkcjonowania psychospołecznego oraz dla tworzenia lepszych strategii leczniczych w przyszłości (Karakuła 2011: 510-515).

Pojęcie wglądu wiąże się też wprost z pojęciami świadomości i nieświadomości. Bycie świadomym oznacza możliwość budowania porządku na bazie chaosu choroby. Jest to rozeznanie swoich mocnych i słabych stron, uczciwe oraz pokorne przyjęcie, iż jest się chorym psychicznie - ale - że nie jest to tragedia a życie może być wartościowe, można zaoferować coś światu, nie pozostając jedynie biernym klientem pomocy społecznej.

\section{Czym jest narracja?}

Jonas Matthew Barrie stwierdził, że „życie każdego człowieka jest dziennikiem, w którym chciałoby się napisać jedną historię, a pisze się inną" (Barrie 1892: 1). Poczucie szczęścia przypomina drganie fal. Gdy jest wygaszone, ludzie czują smutek i przygnębienie. Od wieków poszukuje sięźródeł szczęścia, ale jest to najpewniej kwestia osobnicza - trzeba doszukiwać się go po prostu we własnym wnętrzu, nie jest to jednak zadanie proste. Nie jest bowiem łatwo zapełniać swój dziennik pozytywnymi emocjami i szczęściem płynącym z dobrego życia. Zwłaszcza, gdy przygniata nas cierpienie.

Niezastąpionym źródłem wiedzy na temat zaburzeń psychotycznych są osobiste relacje pacjentów. $Z$ narracji tych wyłania się fakt, że dobrym sposobem walki z chorobą jest prowadzenie pamiętnika. Na jego podstawie powstają dzieła autobiograficzne osób przeżywających kryzysy psychotyczne, które stanowią antidotum na ból i cierpienie, porządkują myśli oraz odczucia związane z chorobą. Można uznać, że świadome i podświadome życie człowieka jest opowieścią zapisywaną w symbolicznej księdze. Zapisy tej księgi nie są łatwo dostępne i zrozumiałe dla przeciętnego odbiorcy. Nawet lekarz psychiatra ma niejednokrotnie problem z ich odczytaniem. Co więcej - mogą one też być niejasne dla samego pacjenta, zwłaszcza na początkowym etapie kuracji. Do prawdy tkwiącej w jego opowieściach oraz zapiskach dochodzi się więc często powoli i z trudem. 
Kategorię „narracji” można interpretować jako pewien rodzaj wiedzy. Jest to wiedza o sobie i o własnym życiu ujęta w ramy słów czy pisma. „Jej zadaniem jest organizowanie ludzkiego doświadczenia, integrowanie różnych jego fragmentów ze sobą wzajemnie i z szerszymi strukturami wiedzy jednostki, a także łączenie doświadczenia z tożsamością osobistą" (Straś-Romanowska, Bartosz, Żurko 2010: 24). Narracja w formie pisania ekspresyjnego pozwala zrozumieć własne doświadczenia oraz nadać im sens, co prowadzi do uporządkowania zdarzeń, dostrzeżenia ich układu sekwencyjnego i odkrycia zależności pomiędzy nimi. Dobra narracja służy też - w przypadku osób zagubionych - rozplątywaniu skłębionych niteczek emocji i reakcji na nie. W tym ujęciu narracja oznacza taką opowieść, która przynosi wglądy, olśnienia i odkrycia, a także ujawnia głębsze, bardziej ogólne znaczenie wydarzeń życia. Możemy zatem przyjąć, że trudności, które przeżywa pacjent, zyskują reprezentację za pośrednictwem narracji. Z tego powodu jest ona dla psychiatry jednym z ważniejszych elementów ułatwiających badanie kliniczne oraz diagnozę. Widzimy więc, że narracja to przede wszystkim sposób rozumienia i interpretowania rzeczywistości - zarówno przez pacjenta, jak i przez lekarza czy terapeutę. To również forma komunikacji między nimi. Bywa tak, że chory ma trudności w wysławianiu się - wówczas pomocne staje się pisanie ekspresyjne. Terapeuta stwarza mu warunki do nakreślenia swojej historii w formie pisemnej. Te cenne zapiski, odpowiednio zinterpretowane, umożliwiają dalszą pracę lekarza z chorym, a w konsekwencji postęp terapii. Przykład takiej sytuacji odnaleźć można w książce Lori Schiller i Amandy Bennett Cichy pokój:

Nienawidziłam mówić komukolwiek o Głosach. Były zbyt potworne, zbyt przerażające. Zabiłyby każdego, kto by się o nich dowiedział. Zabiłyby mnie, gdybym komuś o nich powiedziała. Nie mogłam jej powiedzieć, ale chciałam to zrobić (...) Postanowiłam więc, że jej o tym napiszę (Schiller, Bennett 1994: 121).

\section{Autonarracje}

Mamy więc do czynienia $\mathrm{z}$ autonarracjami, historiami, które ludzie opowiadają o sobie samych. Związane są one mocno z poczuciem własnej tożsamości, która ma charakter narracyjny. Innymi słowy tożsamość jest opowieścią o życiu. Historia rozwija się w czasie równolegle do biegu życia. Tak samo rozwija się tożsamość, ponieważ człowiek nieustannie się formuje i ujmuje siebie we własnej opowieści. Z pewnością więc autonarracje pełnią ważną rolę w procesie kształtowania własnej osobowości.

Co jednak oznacza ta rola i ten proces? Dan P. McAdams - autor jednej z głównych koncepcji tożsamości narracyjnej - wskazuje na integrującą rolę autonarracji, która polega na nadawaniu życiu spójności przez ukierunkowanie na jego sens. Odwołując się do filozofii Paula Ricoeura, powiemy, że narracja łączy w sobie proces działania i proces postaci, dzięki czumu buduje jej tożsamość. Narracja scala motywy, wydarzenia i doświadczenia człowieka. Dzięki opowieściom, którymi obdarowują nas osoby chorujące 
na schizofrenię, potrafimy wytłumaczyć motywy ich działań, a także cechy charakteru i typy relacji, które tworzą. Dokładna i subiektywna narracja umożliwia poznanie Ja pacjenta oraz jego historii. Co więcej - narracja jest zarówno opowiadana, jak i przeżywana. Dzieje się tak, ponieważ nie ma „czystych” przeżyć - są one zawsze uwikłane w jakąś interpretację. Człowiek ma zdolność do artykulacji, czyli objaśniania tychże interpretacji. Jest to ważny punkt w procesie diagnozowania: lekarz musi dobrze zrozumieć sens wypowiedzi swego pacjenta, aby zaproponować odpowiednią dla niego terapię.

Wymienia się wiele powodów konstruowania autonarracji. Dotyczą one trzech grup potrzeb, z którymi są związane:

1. Integracja osobowości, czyli potrzeba ciągłości, spójności i rozumienia zdarzeń.

2. Potrzeby społeczne, czyli potrzeba dzielenia doświadczeń i w nich uczestniczenia.

3. Potrzeby tożsamościowe, czyli samookreślenie, niepowtarzalność i nadawanie sensu własnej egzystencji.

Istotny jest też fakt, iż konstruowanie autonarracji sprzyja odnajdywaniu znaczenia działań, które się podejmuje i własnej roli w życiu. Ponadto formułuje stabilne cele i plany zgodne z wyznawanymi wartościami, opierającymi się na sile własnego wnętrza. Ponieważ to właśnie z wnętrza ludzkiego płynie opowieść o intymnym świecie lęków, bólu i zagubieniu. Również tam znajduje się przepis na wyleczenie.

Jakie wobec tego znaczenie ma autonarracja dla psychiatrii i psychologii? Czy te dziedziny dostatecznie wykorzystują tę metodę? Na pierwszy plan wysuwają się prowadzone wokół narracji badania jakościowe. Służą one zrozumieniu i interpretacji unikalnego kodu wartości oraz znaczeń danej osoby. Zainteresowanie subiektywnym, wewnętrznym doświadczeniem człowieka i tego, jak odbiera on rzeczywistość wynika z tradycji fenomenologicznej i antropologicznej. Fenomenologia zakłada, że aktualna strona percepcji daje nam tylko ograniczony, wyrywkowy i fragmentaryczny ogląd przedmiotu (Sartre 1970: 221). Tak też jest w przypadku narracji osób przeżywających kryzysy psychotyczne. Oprócz choroby mają przecież swoje życie, nie powinni być więc redukowani do swojego zaburzenia lub do wytycznych medycznych dotyczących sposobów leczenia. Psychiatra obserwuje więc objawy, ale nigdy nie powinien uznać, że wie już wszystko o swoim pacjencie - człowieku, którego napotkał na swojej drodze zawodowej w pewnym konkretnym momencie, kiedy ten utracił swoją równowagę. Niemniej, zaletą badań jakościowych jest głębszy kontakt z badanym i możliwość dotarcia do wielu informacji, których nie sposób zebrać w badaniach ilościowych.

Podsumowując - narracja to niejako „relacja z pierwszej ręki”, która pochodzi bezpośrednio od osób chorujących. Możemy określić ich jako ekspertów w zakresie chorób psychicznych, tych, którzy zakosztowali bólu i cierpienia, ale którzy potrafią opisać to, co przeżyli w okresie choroby oraz przed jej wybuchem. Ci ludzie zwracają też uwagę społeczeństwa, jak ważne na drodze zdrowienia jest przywracanie autonomii, posiadanie zaufania otoczenia, podejmowanie samodzielnych decyzji, w tym dotyczących leczenia, budowanie nadziei - a są to czynniki, które mogą zostać pominięte przez terapeutów.

Pisanie autobiograficznej historii ma na celu odzyskiwanie kontroli nad swoim losem. Czytając tekst, wydobywa się z niego spojrzenie poza horyzont objawów klinicznych. 
Dostrzega się całego człowieka, a choroba jest tylko jego fragmentem, choć przecież wyłania się często na pierwszy plan. Można powiedzieć, „że człowiek współczesny ma poważne problemy z ,usensowieniem” własnego istnienia, oparciem własnej tożsamości o stałą, bezwarunkową, a przede wszystkim uniwersalną podstawę" (Tańczuk 1998: 35). Podstawa tożsamości osób chorych psychicznie bywa niestabilna, płynna i rozczłonkowana, kształtuje się przez nieprawidłowe schematy życia, pochodzące z trudnej przeszłości. Jednym ze sposobów integracji tożsamości jest zatem opisanie swoich problemów $\mathrm{w}$ formie opowiadania czy wiersza, tak aby przyjrzeć się sobie, a także pozwolić, by inni spojrzeli na nas. „Konstruowanie tożsamości narracyjnej odbywa się bowiem przez refleksję i samorozumienie, a narracja staje się sposobem, czy też środkiem, za pomocą którego tę tożsamość tworzymy" (Straś-Romanowska 2010: 312).

Tadeusz Woźniak uważa, że świat narracji w przewlekłej psychozie może ulec powolnej erozji, a związki przyczynowo-skutkowe i czasowo-przestrzenne przestają obowiązywać (Woźniak 2005: 213). Badania koncentrujące się na przejawach niespójności w języku osób cierpiących na schizofrenię uwypuklają pojęcie schizofazji - specyficznego zaburzenia mowy, które może wystąpić u tej grupy chorych. Termin schizofazja wprowadził do języka psychiatrii Emil Kraepelin. Stan ten ma się objawiać znacznym rozkojarzeniem myślenia, podczas którego słowa wypowiadane przez pacjenta nie układają się w logiczny ciąg i są chaotycznie przemieszane (za: Klimasiński 2000: 97). Być może jest to interpretacja słuszna w niektórych wypadkach, ale często w subiektywnej, intymnej rzeczywistości wypowiadane słowa mają dla chorującego logiczny sens (albo nabędą go wraz z ewolucją choroby). W takim stanie chory doznaje olśnienia, z zachwytem lub przerażeniem odkrywa nowy, całkiem odmienny świat, który mu się ukazał i wkrótce może go wchłonąć. Jest to pewien rodzaj parawanu oddzielającego dwie płaszczyzny: mrok i chaos pierwszych dni po wybuchu czy zaostrzeniu choroby oraz nowa, sugestywna pewność, dotycząca zmienionej struktury świata i roli, jaką w niej odgrywa podmiot. W angielskiej terminologii psychologicznej mówi się wtedy o „aha feeling” - stanie, gdy z tego chaosu i mgły wyłania się stopniowo nowy obraz rzeczywistości. Można powiedzieć, że obraz ten powstaje jednak w cudzej pracowni - jest choremu narzucony, nadany z góry. Można go tylko przyjąć bez zastrzeżeń, poddać się i próbować współtworzyć w nim swoje życie, a więc znaleźć dla siebie autonomiczny kąt: złudne przekonanie, iż ma się na cokolwiek wpływ. Już w pierwszych dniach od postawienia diagnozy człowiek zaczyna dostrzegać dynamikę swojej choroby, niejednokrotnie wracając do najmłodszych lat życia. Zaczyna konstruować i rekonstruować swoją historię. Czasem sięga po pióro, pozwalając sobie na swobodne zapisywanie i interpretację wydarzeń z życia. Tak powstaje opowieść, saga o złej i dobrej przeszłości.

\section{Analiza wybranych tekstów autobiograficznych}

Lektura autobiograficznych narracji osób chorujących na schizofrenię jest wartościowa oczywiście nie tylko dla personelu medycznego lub rodziny pacjenta. Treść tych tekstów rzuca światło na ważne zagadnienia życia i śmierci, pełnienia ról, egzystencjonalnego 
bólu i cierpienia, świata wartości i filozofii. Stanowi lokum, w którym pojawiają się próby rozumienia świata, tak swojego, jak i całej ludzkości. Kępiński pisał: „A że świat własny jest ściśle zespolony ze światem otaczającym, więc w schizofrenicznym olśnieniu wyjaśnia się zagadka obu. W tajemniczym znaku, magicznym słowie, w zrozumieniu własnego posłannictwa zamyka się w przekonaniu chorego sens zarówno własnego życia, jak i całego świata” (Kępiński 1992: 172).

\section{Metoda biograficzna}

Metodę biograficzną określa się inaczej mianem metody dokumentów osobistych i należy ona do metod badań jakościowych. Tradycyjnie rozumie się przez nią analizę pamiętników, listów, wspomnień lub innych dokumentów o charakterze osobistym. W niniejszej pracy metoda biograficzna służy eksploracji najważniejszych doświadczeń budujących tożsamość człowieka, które są eksplorowane w powieściach autobiograficznych. Poznanie tych obszarów ma na celu przybliżenie zmian dokonujących się we wnętrzu jednostki pod wpływem zachorowania na schizofrenię. Omawiane zagadnienie ujęto z perspektywy podmiotu, którym jest autor opowieści, mając na uwadze to, że zmiana jest pochodną tego, jak się ją odczuwa. Analiza treści wybranych książek polega tu na wyodrębnieniu sekwencji dotyczących zwiastunów choroby psychicznej.

Przyjrzyjmy się więc światom ukazującym się w autonarracjach osób doświadczonych psychozą, posiłkując się wiedzą na temat centralnych objawów tej grupy chorób. A są nimi:

Urojenia - w literaturze dotyczącej schizofrenii wymienia się kilka głównych typów urojeń:

1. Urojenia ksobne (odnoszenia) - dotyczą takiej sytuacji, gdy chory czuje się centralną postacią w swoim otoczeniu. Zwraca uwagę całego społeczeństwa, wszyscy o nim mówią, wszystko do niego się odnosi, każde wydarzenie w jakiś sposób go dotyczy.

2. Urojenia prześladowcze - świat chorego staje się wrogi, grozi klęską i zniszczeniem, przytłacza. Ludzie wokół sprzysięgli się przeciw choremu, snują spiski, śledzą go i przeklinają. Są wyposażeni w tajemnicze urządzenia, które są w stanie wysyłać śmiercionośne fale. Pożywienie jest zatrute, cały świat skażony.

3. Urojenia wielkościowe i posłannicze - rola społeczna pacjenta urasta do karykaturalnych rozmiarów. Są przeciwnością urojeń prześladowczych, ponieważ samopoczucie jest tu wzmożone, nastrój podniesiony. Charakter misji (posłannictwa) jest rozmaity - patriotyczny, religijny, polityczny, naukowy, artystyczny i tak dalej. Chory jest niejednokrotnie gotowy, aby poświęcić dla swej misji życie.

4. Urojenia nicości - są antytezą urojeń wielkościowych. Chory czuje się najgorszy ze wszystkich ludzi, zakałą społeczeństwa, wielkim NIC. Poczucie tej nicości może się przenieść na własne ciało, które zmienia się w zgniłe i spleśniałe ścierwo, a narządy wewnętrzne przestają normalnie funkcjonować. 
5. Urojenia katastroficzne - świat pacjenta doświadczającego tych urojeń ulega zagładzie. Światem tym może być dom, rodzina, lub dalsze otoczenie, nawet cały kosmos. Chory może mieć przeświadczenie, że wszyscy, którymi się interesuje, z jakiegoś przerażającego powodu umrą. Jedynym ratunkiem jest śmierć: $\mathrm{w}$ urojeniowej ocenie pacjent może nawet zabić osoby, które kocha i sam odebrać sobie życie.

6. Urojenia hipochondryczne - chory ma przeświadczenie, że w jego ciele „coś się zepsuło”, „nie spisuje się dobrze”. Niepokój związany z własnym ciałem zmienia się w urojenia, gdy powstanie gotowa, niezgodna ze stanem faktycznym odpowiedź.

Depersonalizacja i derealizacja - zaburzeniem jest tutaj utrata poczucia rzeczywistości zarówno własnego ciała, jak i otaczającego świata. Chory ma wątpliwość co do realności swego ciała, które zdaje się być odmienione, na przykład jakaś jego część puchnie lub wydłuża się. Derealizacja występuje, gdy świat jawi się jak ze snu lub filmu, przypomina teatralną makietę, staje się odległy, obcy, płaski.

Halucynacje (omamy) - przede wszystkim wzrokowe, słuchowe, somatyczne, cenestetyczne (zaburzenia percepcji ciała).

Lęk - uczuciem najczęściej spotykanym w schizofrenii jest lęk, który ma przede wszystkim charakter dezintegracyjny. Rujnuje strukturę świata wewnętrznego i zewnętrznego pacjenta. Doświadczenia kliniczne pokazują, że najbardziej nasilony lęk występuje w pierwszej, ostrej fazie choroby zwanej owładnięciem. Przeżycia chorego znacznie odbiegają wówczas od dotychczasowych, co prowadzi do poczucia osaczenia przez nieznane i groźne siły zewnętrzne.

\section{Życie to nie bajka}

Aby przybliżyć temat objawów chorób psychicznych, poznajmy historię napisaną przez Joanne Greenberg w książce Życie to nie bajka (1994). Deborah, bohaterka tejże powieści, walczy ze swoimi demonami - postaciami z jej urojonego świata zwanego Ur. Ta fascynująca opowieść na wątkach autobiograficznych zawiera w sobie liczne elementy, które świadczą o targającej autorką chorobie. Wymieńmy choć kilka:

Urojenia prześladowcze:

1) Zaczęła spadać, przemieszczając się wraz z Anterrabae przez upstrzoną ognikami ciemność do Ur. Tym razem upadek był długi. Przez długi czas panowała całkowita ciemność, potem szarość, widziana przez opaskę na oczach. Znała to miejsce - to Otchłań. Bogowie i Kolektywa jęczeli i krzyczeli, ale nawet ich słowa były niezrozumiałe (Greenberg 1994: 28).

2) „Jak śmiesz przestawać ze światem! Zostaniesz ukarana, zdrajczyni!” Droga do Ur zamknęła się przed nią. - „Nie! Nie! Jeśli to zrobicie, zwariuję!” - zawołała do nich. 
3) W tej samej chwili zbliżyło się ku niej zwierciadło krańcowego oszustwa, Przyjście Oczekiwanej Śmierci. - „Widzę cię, Imorth” - powiedziała Deborah, po raz pierwszy odzywając się na głos po uryjsku w obecności kogoś obcego (Greenberg 1994: 136).

\section{Urojenia wielkościowe i nicości:}

Później zaczęly omawiać [Deborah ze swoją lekarką - wtrącenie M.G.] skrywane przedtem przeświadczenie Deborah, które dzieliła ze wszystkimi chorymi psychicznie - że posiada nieskończenie większą potęgę niż zwyczajna osoba, a jednocześnie jest czymś gorszym (Greenberg 1994: 149).

\section{Halucynacje (w tym prowadzące do autoagresji):}

1) Ur sprzysięgło się przeciw niej, gdy wróciła na oddział. Siedząc na twardym krześle, słuchała krzyków i wrzasków Kolektywy i pomruków z niższych poziomów Ur. - „Posłuchaj Ptaszko; posłuchaj, Dziki Koniu: ty nie jesteś z nich!” - Słowa te skazywały ją na wieczne bytowanie w Ur. - „Spójrz na mnie!” Anterrabae spadał, mówiąc: - „Na wieki igrasz z Otchłanią. Spacerujesz z własnym zniszczeniem, dźgając ją palcem. Złamiesz pieczęć. Znajdziesz swój kres” (Greenberg 1994: 50-51).

2) Pewnego razu przyszło do niej [do Deborah - M.G.] Idat, Bóstwo o Wielu Postaciach, jako kobieta. (...) Podczas tej wizyty Idat opuściła woal i ukazała się cała w bieli. - „Czemu jesteś w bieli, Idat?” „Całun i suknia ślubna to jedno. Winnaś żyć umierając i umierać żyjąc; winnaś poddać się walcząc i walczyć poddając się. U mnie jedna droga zmierza do wszystkich sprzeczności, jedne środki do przeciwstawnych celów. Pomyśl, jak ludzie gaszą pożar: zapalają przeciwogień”. (...) Deborah pojęła, że płonąc, rozpali przeciwogień, który stłumi pożar w piecu wulkanu (...). Jednocześnie zaś płonąc, mogła się nareszcie przekonać, czy naprawdę uczyniona jest z ludzkiej substancji. Jej zmysły nie dawały na to dowodu. (...) Wkrótce miała zapałki i zapas papierosów. Zapaliła pięć z nich i zaczęła trawić ogniem swą powierzchowność. (...) Pojawiły się lekkie wrażenia dotykowe i swąd palonego ciała, lecz wulkan gorzał równie intensywnie, jak przedtem (Greenberg 1994: 162).

3) - Cierpcie - powiedziała Deborah do wszystkich zgromadzonych w Ur, co było formą uryjskiego pozdrowienia. - jestem przewodnikiem błyskawic i oparzeń. Przechodzą przeze mnie z lekarki na pielęgniarkę (...). Anterrabae zaśmiał się. - „Bądź dowcipna” - powiedział, siejąc skry w swym nie kończącym się upadku w ogniu, który go nie trawił. - „Kiedy skończy się zmiana [w rozumieniu zmiany dyżuru personelu w szpitalu - M.G.], ona śmieje się, chodzi, oddycha w żywiole, którego nigdy nie zaznasz i nie zrozumiesz. Ich wdech i wydech, ich krew, kości, noc i dzień nie są z tej samej substancji, co twoje. Twoja substancja jest dla nich zgubna. Jeżeli zarazisz ich swoim żywiołem, umrą lub postradają rozum” - „Jak w Otchłani?” - „Dokładnie tak”. Deborah wzniosła okrzyk przerażenia nad swą mocą zniszczenia. Upadła na podłogę, jęcząc z cicha: - Zbyt wielka moc, zbyt wielkie rany. Nie pozwólcie nikomu tak ranić! (Greenberg 1994: 100-101).

4) Wrzawa Kolektywy narastała, aż przeszła w ogłuszający ryk, a szarość poczerwieniała. Bez żadnego ostrzeżenia, jak ramię kata spadła na nią Kara. Świadectwo światła, przestrzeni, czasu, ciążenia i pięciu zmysłów straciło wszelkie znaczenie. Upał zamarzł, a światło miotało kłującymi promieniami. Nie miała poczucia, gdzie znajduje się jej ciało; nie było góry ani dołu, umiejscowienia ani odległości, łańcucha przyczyn i skutków (Greenberg 1994: 165). 
Lęk:

Powoli pod jej niewzruszoną, podobną masce twarzą zaczął wzbierać wulkan; w jego kamiennych otchłaniach zaczęły kipieć głosy i przeciwgłosy, nienawiść, pragnienia i przewlekłe lęki. W górę krateru wzbijała chmura gorącej pary (Greenberg 1994: 162).

Autoagresja:

Położyła się na zimnej posadzce i zaczęła powoli i metodycznie tłuc głową w kafelki. Czerń w jej głowie poczerwieniała, nabrzmiała i wydostała się na zewnątrz: Deborah była spowita wściekłym gniewem erupcji. Kiedy odzyskała wzrok, widziała jak przez dziurkę od klucza. Miała świadomość, że krzyczy, w pomieszczeniu są salowi, a na ścianach wypisane są słowa i zdania po uryjsku. Były to wyziewy nienawiści, gniewu i goryczy w języku, w którym „złamany” znaczyło „zgodliwy”, a „trzecia szyna” znaczyło „posłuszny” (Greenberg 1994: 178).

Książka kończy się dość optymistycznie, Deborah poczyniła znaczne postępy w leczeniu i powoli powraca do równowagi psychicznej. Niebywałą zasługą Greenberg jest opisanie rzeczywistości szpitala psychiatrycznego w latach, kiedy nie były dostępne jeszcze leki przeciwpsychotyczne. Pokazuje także siłę psychoterapii w zwalczaniu choroby, siłę, która wówczas musiała nieomal samodzielnie rozprawić się z przeszłością i teraźniejszością pacjenta i poprowadzić go do zdrowia.

\section{Podsumowanie}

Lektura autobiograficznych książek chorujących twórców dostarcza cennych wskazówek diagnostycznych i jest źródłem wiedzy, jakie objawy mogą wystąpić u osoby doświadczonej psychozą. Pozwala też spojrzeć na tekst okiem terapeuty, który zdolny jest wychwycić te elementy, które świadczą o postępie choroby. Trzeba jednak uniknąć pułapki, jaką może być patologizacja narracji osób z zaburzeniami psychotycznymi. Ich historie opowiadają o życiu, a choroba jest tylko jego fragmentem. Należy szukać tego, co zdrowe i pożyteczne, aby wzmocnić te składniki życiowego doświadczenia. Służy to budowaniu podmiotowości chorującego człowieka oraz efektywnemu szukaniu rozwiązań jego problemów. Daje bowiem nadzieję na pozbycie się przykrych objawów i dobre życie.

W niniejszym artykule starałam się przekazać czytelnikom, że, jak napisała Arnhild Lauveng w swojej doskonałej książce Byłam po drugiej stronie lustra, trzeba dostrzegać cały świat chorego i nigdy nie redukować go do samych objawów:

Jeśli mamy zrozumieć konkretnego człowieka, musimy patrzeć tyleż na niego, co na całokształt. Nigdy zapewne wszystkiego i tak nie zrozumiemy, ale być może nieco więcej, niż gdybyśmy trzymali się tylko diagnozy. Diagnozy bowiem zaledwie opisują rzeczywistość. Jeśli mamy zrozumieć musimy przyjrzeć się człowiekowi (Lauveng 2008: 78). 
Ważne jest właśnie to, aby zobaczyć w pojawiających się symptomach pewną prawdę o człowieku. Joanne Greenberg napisała z kolei pod koniec swojej książki: „Och, Deborah! Zdrowie nie jest po prostu brakiem choroby. Nie po to pracowałyśmy tak ciężko, żebyś była tylko niechora!" (Greenberg 1994: 248).

Świat zatrzymany na kartach powieści to dojmujący list, który chorujące osoby wysyłają ludziom zdrowym. Chcą w ten sposób nie tylko wykroczyć poza swoje cierpienie, ale przede wszystkim dać świadectwo, że istnieją i ich życie jest równie wartościowe, co życie każdego innego człowieka. Zdrowie i choroba są bowiem sobie niezwykle bliskie. Łatwo jest upaść, ale ciężko podnieść się i ruszyć w dalszą podróż zwaną życiem. Na szczęście na tej drodze nikt nie musi być sam. Można z ufnością zwrócić się o pomoc, gdyż doświadczenie setek tysięcy ludzi chorujących psychicznie, wyrażone w ich narracjach, pokazuje, że z chorobą da się żyć, a nawet można ją zażegnać, jeśli nie na zawsze, to na wiele lat, a egzystencja ta może być rzeczywiście satysfakcjonująca. Świat ludzi chorych jest po prostu inną manifestacją naszego wspólnego doświadczenia.

\section{Bibliografia}

Barrie J.M. (1892). Tajemnicza cyganka. Druk. Noskowskiego, Warszawa.

Bartosz B., Straś-Romanowska M. (2010). Badania narracyjne w psychologii. Wydawnictwo Psychologii Kultury, Warszawa.

Bennett A., Schiller L. (1994). Cichy pokój, tłum. P. Laskowicz. Wydawnictwo Zysk i S-ka, Poznań. Frankl V. (2013). Człowiek w poszukiwaniu sensu, tłum. A. Wolnicka. Wydawnictwo Czarna Owca, Warszawa.

Golańska Ż. (2007). Opieka pieleggniarska nad noworodkiem. Wydawnictwo Medycyna Praktyczna, Kraków.

Greenberg J. (1994). Życie to nie bajka, tłum. T. Bieroń. Wydawnictwo Zysk i S-ka, Poznań. Karakuła H., Krasowski T., Morylowska-Topolska J., Pawęzka J., Stelmach E., Urbańska A. (2011). Wgląd w chorobę a zaburzenia poznania społecznego w schizofrenii - przeglad literatury. „Current Problems of Psychiatry”, 12 (4): 510-515.

Kępiński A. (1992). Schizofrenia. Wydawnictwo Sagittarius, Kraków.

Kępiński A. (2001). Autoportret człowieka. Myśli-aforyzmy. Wydawnictwo Literackie, Kraków. Kirchbach G. (2003). Ogólne wprowadzenie do logoterapii i analizy egzystencjalne. „European Psychotherapy", 1 (4): 33-46.

Klimasiński K. (2000). Elementy psychopatologii i psychologii klinicznej. Wydawnictwo Uniwersytetu Jagiellońskiego, Kraków.

Kuhn-Dymecka A., Niedźwiecka I., Wciórka J. (2008). Wglad w chorobę a funkcjonowanie poznawcze osób chorych na schizofrenię. „Psychiatria Polska”, 42 (6): 943-957.

Lauveng A. (2008). Byłam po drugiej stronie lustra, tłum. E. Bilińska. Wydawnictwo Smak Słowa, Sopot.

Paul-Cavallier F. (2001). Wizualizacja, tłum. A. Suchańska. Dom Wydawniczy Rebis, Poznań. 
Saint-Exupéry A. (1993). Ziemia, planeta ludzi, tłum. W. Bieńkowska, Z. Bieńkowski. Państwowy Instytut Wydawniczy, Warszawa.

Sartre J.-P. (1970). Wyobrażenie. Fenomenologiczna psychologia wyobraźni, tłum. P. Beylin. Państwowe Wydawnictwo Naukowe, Warszawa.

Schulz B. (2002). Księga listów. Wydawnictwo Słowo/Obraz Terytoria, Gdańsk.

Tańczuk R. (1998). Współczesne kłopoty z tożsamością. „Teraźniejszość - Człowiek - Edukacja", $1: 31-45$.

Woźniak T. (2005). Narracja w schizofrenii. Wydawnictwo Uniwersytetu Marii Curie-Skłodowskiej, Lublin. 